\title{
Karyotype analysis and chromosome number for two Cirsium taxa (Asteraceae) in Iran
}

\author{
Z. Babaee ${ }^{1,3}$, M. Norouzi ${ }^{2,6}$, S. Mosaferi ${ }^{1,4 *}$, M. Keshavarzi1 ${ }^{1,5}$ \\ ${ }^{1}$ Department of Plant Sciences, Faculty of Biological Sciences, Alzahra University, North Sheikh \\ Bahaee St., Deh-e Vanak, Tehran, Iran \\ ${ }^{2}$ Department of Horticulture, College of Aburaihan, University of Tehran, Tehran, Iran \\ ${ }_{3}^{3}$ E-mail: zohrehbabaee74@gmail.com; ORCID iD: https://orcid.org/0000-0002-5277-6260 \\ ${ }^{4}$ E-mail: s.mosaferi@alzahra.ac.ir; ORCID iD: https://orcid.org/0000-0003-0501-6637 \\ ${ }^{5}$ E-mail: m.keshavarzi@alzahra.ac.ir; ORCID iD: https://orcid.org/0000-0003-3032-9408 \\ ${ }^{6}$ E-mail: mnorouzi91@ut.ac.ir; ORCID iD: https://orcid.org/0000-0003-1855-7600 \\ * Corresponding author
}

Keywords: Asteraceae, B-chromosome, Cirsium, karyology, mitotic study.

Summary. Cirsium Mill. contains more than 250 species in the world mainly distributed in the Northern hemisphere. Different chromosome numbers with different ploidy levels were reported in this genus. In this study, karyotype details and chromosome numbers were established for two Cirsium taxa in Iran. C. ciliatum subsp. szovitsii and C. echinus had the mitotic chromosome numbers of $2 n=2 x=34$. Karyotype analyses showed that chromosomes were generally metacentric and sub-metacentric. In C. echinus, Lowshan population had the longest chromosome $(19.10 \mu \mathrm{m})$ and Heyran Canyon population $(4.73 \mu \mathrm{m})$ the shortest one while in C. ciliatum, the longest chromosome was observed in Urmia to Salmas population $(14.67 \mu \mathrm{m})$ and the shortest one $(4.71 \mu \mathrm{m})$ in Doshanlu population. Total haploid chromosome length ranged from 275.29 to $376.42 \mu \mathrm{m}$ in populations studied. Both taxa were grouped in 2B class. B-chromosomes were recorded for two taxa studied too. Chromosome type, mitotic chromosome numbers and occurrence of B-chromosomes were in agreement with previous results (Albers, Pröbsting, 1998; Lövkvist, Hultgård, 1999; Yüksel et al., 2013; Yildiz et al., 2016).

\section{Анализ кариотипа и число хромосом двух видов Cirsium (Asteraceae) флоры Ирана}

\author{
3. Бабаи ${ }^{1}$, М. Норузи르, С. Мосафери ${ }^{1}$, М. Кешаварзи ${ }^{1}$ \\ ${ }^{1}$ Кафедра ботаники, биологический факультет, Университет Аль-Захра, ул. Северного Шейха Бахаи, \\ Дех-э Ванак, г. Тегеран, 1993891176, Иран \\ ${ }^{2}$ Кафедра садоводства, Колледж Абураихана, Тегеранский университет, 16-я улица Азара, \\ площадь Энгелаб, г. Тегеран, 1417466191, Иран
}

Ключевые слова: В-хромосома, кариология, митотическое исследование, Asteraceae, Cirsium.

Аннотация. В мировой флоре род Cirsium Mill. содержит более 250 видов, в основном распространенных в Северном полушарии. Для видов этого рода характерно варьирование числа хромосом и кариотипы с разным уровнем плоидности. Для Cirsium ciliatum subsp. szovitsii и C. echinus, произрастающих в Иране, установлено 
митотическое число хромосом $2 n=2 x=34$. Кариотип обоих видов представлен в основном метацентрическими и субметацентрическими хромосомами. У C. echinus наибольшая длина хромосомы (19,10 мкм) отмечена в популяция из окр. г. Ловшан, наименьшая (4,73 мкм) - в популяции из каньона Хейран. Для C. ciliatum эти значения составили, соответственно, 14,67 (популяция из окг. г. Сельмас) и 4,71 мкм (популяция из окр. дер. Дошанлу). В изученных популяциях длина гаплоидных хромосом варьирует от 275,29 до 376,42 мкм. Оба таксона отнесены к классу 2В, у обоих зарегистрированы В-хромосомы. Выявленные особенности и значения (тип хромосом, число митотических хромосом и встречаемость В-хромосом) согласуются с результатами предыдущих исследований (Albers, Pröbsting, 1998; Lövkvist, Hultgård, 1999; Yüksel et al., 2013; Yildiz et al., 2016).

\section{Introduction}

Cirsium Mill. (Asteraceae) with more than 250 taxa is a large genus that is distributed in holarctic with several diversification centers (Zomlefer, 1994). These taxa show high diversity from the northern Mediterranean area over to Caucasus (Häffner, Hellwig, 1999). Cirsium species are classified in five sections, as Pseudepitrachys Petrak, Echenias (Cass.) Petrak, Cephalonoplos (Neck.) DC., Cirsium and Epitrachys DC. in Iran (Petrak, 1979).

The first chromosome counting for Cirsium dated back to Aishima (1934) as $x=17$ and two ploidy levels (diploid and tetraploid) were defined. Frankton and Moor (1963) proposed $x=17$ for the elements of tribe Cardueae. The presence of aneuploidy in Cirsium of the new world was recorded by Ownbey and Olson (1969). Some of the cytological studies in this genus related to the definition between Cirsium and Carduus L., based on the basic chromosome number (Frankton, Moore, 1961; Hedberg I., Hedberg O., 1977). Some researches illustrated that the lower chromosome number was correlated with the more assymetrical chromosomes. Bureš et al. (2004) studied the chromosomes of 17 Cirsium species and stated that B-chromosome presence had significant effect on the increase or decrease of chiasmata frequency and the obtained genetic variation in gametes.

The cytological studies of Cirsium in Turkey showed different chromosome numbers of $2 n=$
32, 34, 60 and 68 (Melahat et al., 2008). The most common chromosome number was $2 n=34$ (diploids) and $2 n=68$ (tetraploids). Nourouzi et al. (2010) studied meiosis in 17 Cirsium species of Iran. They recorded 0-2 B-chromosomes. Meiotic abnormalities were recorded in some species. Yüksel et al. (2013) studied the karyotype properties of 10 Cirsium species of sect. Epitrachys in Turkey.

Despite much attention to the taxonomy and morphology of Cirsium species, karyological records for the genus are scarce. Karyology of Iranian Cirsium species has been studied to clarify their taxonomy and make contributions to other multidisciplinary studies on the genus (Nouroozi et al., 2010, 2011; Sheidai et al., 2012). In this study karyotype analyses and chromosome numbers of two Cirsium taxa are presented.

\section{Materials and Methods}

Karyotype study was done on two Cirsium taxa: C. echinus (M. Bieb.) Hand.-Mazz. and C. ciliatum subsp. szovitsii (K. Koch) Petr. To achieve the chromosome numbers of taxa studied, six accessions including four accessions of $C$. echinus and two accessions of $C$. ciliatum subsp. szovitsii were gathered from nature (Table 1). Cypselas were sterilized by $50 \% \mathrm{H}_{2} \mathrm{O}_{2}$ for $10-15 \mathrm{~min}$., washed by sterile water for 5 min., then put in Petri dishes and kept at room temperature until germination. Growing root tips with $1-2 \mathrm{~cm}$ in length were pretreated with

Table 1

Voucher details of Cirsium taxons studied

\begin{tabular}{|c|c|c|}
\hline Locality, collector and voucher number & $\begin{array}{l}\text { Pop } \\
\text { no. }\end{array}$ & Taxon \\
\hline $\begin{array}{l}\text { Gilan prov., Asalem to Khalkhal, Asbdavani village, } 2000 \text { m, Norouzi, Babaee } \\
\text { (ALUH 910) }\end{array}$ & 1 & \\
\hline Gilan prov., Rudbar, Lowshan, 353 m, Norouzi, Babaee (ALUH 912) & 2 & C. echinus (M. Bieb.) \\
\hline Gilan prov., Astara, Heyran Canyon, 860 m, Norouzi, Babaee (ALUH 908) & 3 & \\
\hline East Azerbaijan prov., Kiamaky Canyon, 1999 m, Norouzi, Babaee (ALUH 909) & 4 & \\
\hline Ardebil prov., Meshgin Shahr, Doshanlu, 1170 m, Norouzi, Babaee (ALUH 902) & 5 & C. ciliatum subsp. \\
\hline West Azerbaijan prov., Urmia to Salmas, 1282 m, Norouzi, Babaee (ALUH 904) & 6 & $\begin{array}{l}\text { szovitsii (K. Koch) } \\
\text { Petr. }\end{array}$ \\
\hline
\end{tabular}


$0.002 \mathrm{~m}$ 8-hydroxyquinoline for 3 hours at $4{ }^{\circ} \mathrm{C}(7-9$ $\mathrm{AM})$. Then they were fixed with Carnoy solution (1: 3 glacial acetic acid/absolute ethanol) for $24 \mathrm{~h}$. at $4{ }^{\circ} \mathrm{C}$. Materials were hydrolyzed in $1 \mathrm{~N} \mathrm{HCl}$ for 20 min. at $60{ }^{\circ} \mathrm{C}$ bath and washed by sterile water.

Meristematic regions were stained with $1 \%$ aqueous Aceto-orcein for $60 \mathrm{~min}$. at $60^{\circ} \mathrm{C}$ bath and squashed on slides with one drop of $45 \%$ glacial acetic acid. At least 5-10 well prepared metaphase plates for each population were photographed with Olympus BX-51 microscope and measured by IdeoKar 1.0 software.

The chromosomes were identified based on Levan et al. (1964). Karyotype asymmetry indices as variation of chromosome length $\left(\mathrm{CV}_{\mathrm{CL}}\right)$ (Paszko, 2006), coefficient variation of centromeric index $\left(\mathrm{CV}_{\mathrm{CI}}\right)$, mean centromeric asymmetry $\left(\mathrm{M}_{\mathrm{CA}}\right)$ and mean centromeric index $\left(\mathrm{M}_{\mathrm{CI}}\right)$ (Paszko, 2006) and intra and inter-chromosomal asymmetry (A1 and A2 respectively) (Zarco, 1986) were determined.

\section{Results}

In present study, karyotype analyses were done for two taxa (C. echinus and C. ciliatum subsp. szovitsii). Chromosome counts were $2 n=2 x=34$ with the basic chromosome number $n=17$ (Table 2). Based on Stebbins symmetry class, populations of two taxa studied were grouped in 2B class. The taxa studied differed in karyotype formula. They had metacentric (m) and sub-metacentric (sm) chromosomes (Figs 1, 2). In studied populations of C. echinus, the longest chromosome was observed in Lowshan population and the smallest in Heyran Canyon one. Among populations studied of C. ciliatum subsp. szovitsii, the longest chromosome $(14.67 \mu \mathrm{m})$ was observed in Urmia to Salmas population and the shortest one $(4.71 \mu \mathrm{m})$ was observed in Doshanlu population.

Lowshan population of $C$. echinus had the longest chromosome length $(19.10 \mu \mathrm{m})$ and Doshanlu population of $C$. ciliatum subsp. szovitsii had the shortest $(4.71 \mu \mathrm{m})$. Doshanlu population of $C$. ciliatum subsp. szovitsii had the shortest total haploid length $(275.29 \mu \mathrm{m})$ while Heyran canyon population of $C$. echinus had the longest $(376.42 \mu \mathrm{m})$. A1 index varied from 0.28 in Doshanlu population of $C$. ciliatum subsp. szovitsii to 0.36 in Lowshan population of C. echinus. A2 index ranged from 0.27 (Doshanlu population of C. ciliatum subsp. szovitsii) to 0.40 (Kiamaky Canyon population of $C$. echinus). The highest value of coefficient variation of centromeric index $\left(\mathrm{CV}_{\mathrm{CI}}\right)$ was observed in Urmia to Salmas population of C. ciliatum subsp. szovitsii (18.35) and the lowest value of $\mathrm{CV}_{\mathrm{CI}}$ was observed in Lowshan population of C. echinus (14.91). Kiamaky Canyon population of $C$. echinus showed the highest value of coefficient variation of chromosome length $\left(\mathrm{CV}_{\mathrm{CL}}\right)(39.82)$ and Doshanlu population of $C$. ciliatum subsp. szovitsii showed the lowest (26.77).

Table 2

Summary of karyotype features in Cirsium populations studied

\begin{tabular}{|c|c|c|c|c|c|c|c|c|c|c|c|c|c|}
\hline KF & ST & $\mathrm{TF} \%$ & $\mathrm{M}_{\mathrm{CI}}$ & $\mathrm{M}_{\mathrm{CA}}$ & $\mathrm{CV}_{\mathrm{CL}}$ & $\mathrm{CV}_{\mathrm{CI}}$ & THL & $\mathrm{L} / \mathrm{S}$ & $\begin{array}{c}\text { Range } \\
\text { S-LL }\end{array}$ & $\mathrm{A} 2$ & $\mathrm{~A} 1$ & $\begin{array}{l}\text { Pop } \\
\text { no. }\end{array}$ & Taxon \\
\hline $\begin{array}{c}12 \mathrm{~m}+ \\
5 \mathrm{sm}\end{array}$ & $2 \mathrm{~B}$ & 39.53 & 0.40 & 20.86 & 28.52 & 14.95 & 355.81 & 2.25 & $\begin{array}{l}6.95- \\
15.62\end{array}$ & 0.29 & 0.33 & 1 & \multirow{4}{*}{$\begin{array}{c}C . \\
\text { echinus }\end{array}$} \\
\hline $\begin{array}{c}14 \mathrm{~m}+ \\
3 \mathrm{sm}\end{array}$ & $2 \mathrm{~B}$ & 38.32 & 0.38 & 23.20 & 29.65 & 14.91 & 328.71 & 2.76 & $\begin{array}{l}6.92- \\
19.10\end{array}$ & 0.30 & 0.36 & 2 & \\
\hline $\begin{array}{c}12 \mathrm{~m}+ \\
5 \mathrm{sm}\end{array}$ & $2 \mathrm{~B}$ & 39.86 & 0.39 & 21.26 & 32.54 & 17.77 & 376.42 & 3.82 & $\begin{array}{l}4.73- \\
18.06\end{array}$ & 0.33 & 0.33 & 3 & \\
\hline $\begin{array}{c}13 \mathrm{~m}+ \\
4 \mathrm{sm}\end{array}$ & $2 \mathrm{~B}$ & 39.60 & 0.40 & 20.41 & 39.82 & 17.58 & 322.03 & 2.86 & $\begin{array}{l}5.46- \\
15.61\end{array}$ & 0.40 & 0.32 & 4 & \\
\hline $\begin{array}{c}12 \mathrm{~m}+ \\
5 \mathrm{sm}\end{array}$ & $2 \mathrm{~B}$ & 41.39 & 0.41 & 17.88 & 26.77 & 16.90 & 275.29 & 2.72 & $\begin{array}{l}4.71- \\
12.83\end{array}$ & 0.27 & 0.28 & 5 & \multirow{2}{*}{$\begin{array}{c}C . \\
\text { ciliatum } \\
\text { subsp. } \\
\text { szovitsii }\end{array}$} \\
\hline $\begin{array}{c}12 \mathrm{~m}+ \\
5 \mathrm{sm}\end{array}$ & $2 \mathrm{~B}$ & 40.21 & 0.40 & 19.32 & 28.36 & 18.35 & 304.40 & 2.80 & $\begin{array}{l}5.25- \\
14.67\end{array}$ & 0.28 & 0.30 & 6 & \\
\hline
\end{tabular}

Abbreviations: A1: intrachromosomal asymmetry, A2: interchromosomal asymmetry, S: size of the shortest chromosome pair, L: size of the longest chromosome pair, THL: total haploid length, $\mathrm{CV}_{\mathrm{Cl}}$ : coefficient variation of centromeric index, $\mathrm{CV}_{\mathrm{CL}}$ : variation of chromosome length, $\mathrm{M}_{\mathrm{CA}}:$ mean centromeric asymmetry, $\mathrm{M}_{\mathrm{CI}}$ : mean centromeric index, TF: total form percentage, ST: Stebbins' symmetry class, KF: karyotype formulae.

Lowshan population of $C$. echinus was characterized by the lowest value of mean centro- meric index $\left(\mathrm{M}_{\mathrm{CI}}\right)(0.38)$ and total form percentage (TF \%) (38.32) while Doshanlu population of 
C. ciliatum subsp. szovitsii was characterized by the highest value of $\mathrm{M}_{\mathrm{CI}}(0.41)$ and $\mathrm{TF} \%$ (41.39). These two population had the highest (23.20) and the lowest (17.88) value of mean centromeric asymmetry $\left(\mathrm{M}_{\mathrm{CA}}\right)$ vice versa.

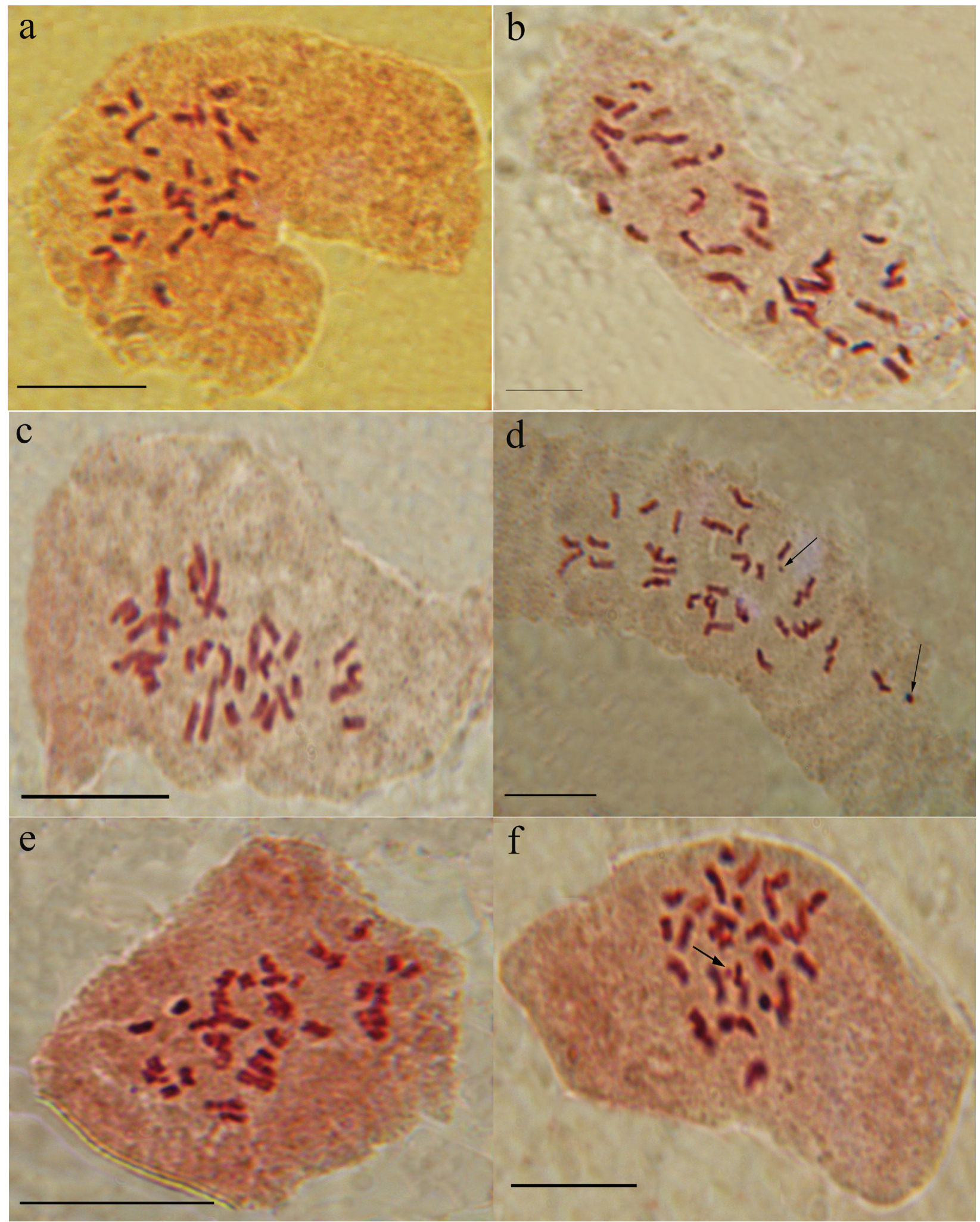

Fig. 1. Somatic chromosomes of Cirsium taxa studied: a - Asbdavani village population; b - Lowshan population; c - Heyran Canyon population; $\mathrm{d}$ - Kiamaky Canyon population in C. echinus; e - Doshanlu population; $\mathrm{f}-\mathrm{Urmia}$ to Salmas population of C. ciliatum subsp. szovitsii (scale bar: 50 micrometers; Arrows show the B-chromosome). 

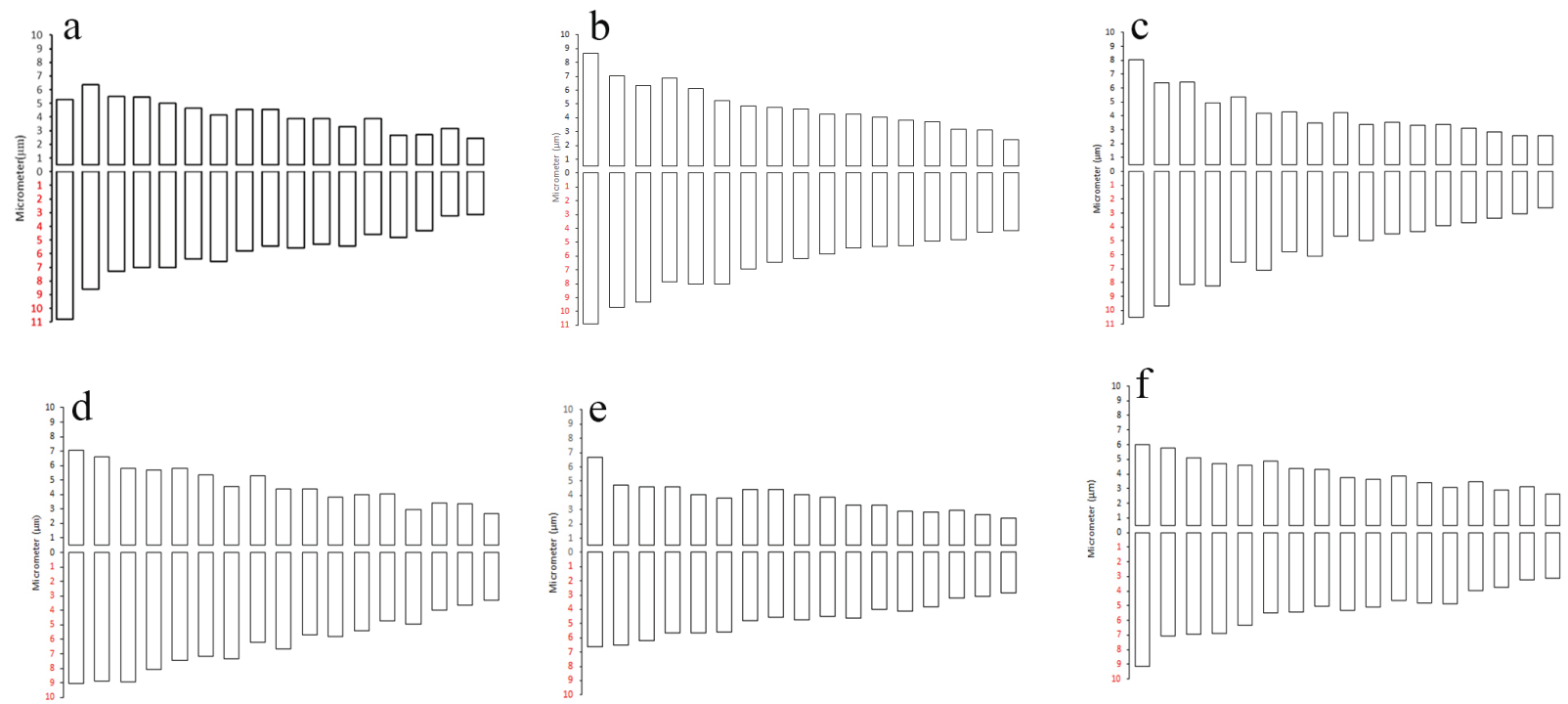

Fig. 2. Haploid ideograms of Cirsium taxa studied: a - Asbdavani village population; $\mathrm{b}$ - Lowshan population; $\mathrm{c}-$ Heyran Canyon population; d - Kiamaky Canyon population of C. echinus; e - Doshanlu population; f - Urmia to Salmas population of $C$. ciliatum subsp. szovitsii.

\section{Discussion}

Obtained chromosome counts for $C$. ciliatum subsp. szovitsii and C. echinus $(2 n=2 x=34)$ were in concordant with the previous findings of Tonian (1981, 1982), Yüksel et al. (2013) and Yildiz et al. (2016). Most Cirsium species are diploid $(2 n=34)$ (Ownbey et al., 1975). In Armenia, chromosome count for $C$. ciliatum was recorded as $2 n=4 x=$ 68 (Tonian, 1982) while in Turkey Melahat et al. (2008) recorded $2 n=2 x=34$. Nouroozi et al. (2010) recorded miotic chromosome number in 17 species of Cirsium with chromosome numbers of $2 n=2 x=$ 34 and $2 n=4 x=68$. There is no report on mitotic number of Cirsium species in Iran.

In present study, chromosome length varies between 4.71 to 19.10 micrometer. The ratio of longest to shortest chromosome varies between 2.25 to 3.82. Yüksel et al. (2013) analyzed the karyotype features of ten Cirsium species of sect. Epitrachys in Turkey. They stated that generally the chromosome number for these species is $2 n=2 x=34$ and the chromosome length is of taxonomic use to separate species.
Karyotype analyses showed that Cirsium species are of $\mathrm{m}$ and $\mathrm{sm}$ types that is in agreement with Yüksel et al. (2013). Based on karyotype asymmetry parameters, Doshanlu population of C. ciliatum subsp. szovitsii had higher value of $\mathrm{TF} \%$ and represented more symmetrical karyotype. Lowshan population of $C$. echinus with the highest value of A1 index showed more asymmetrical karyotype.

In present study, B-chromosome are recorded for the two taxa studied for the first time in Iran. B-chromosomes were 0 to 2 in species studied, rounded and very smaller than A-chromosomes. B-chromosomes were recorded for some Cirsium species as C. acaule (L.) Scop. (0-2) (Lövkvist, Hultgård, 1999), C. arvense (L.) Scop. (0-1) (Lövkvist, Hultgård, 1999) and C. oleraceum Scop. (0-2) (Albers, Pröbsting, 1998). B-chromosomes are present in both diploid and tetraploid Cirsium species so it seems that there is no advantage for their occurrence due to ploidy levels. Further studies of the karyotype properties will have implications in the systematics of the genus Cirsium in Iran.

\section{REFERENCES}

Aishima T. 1934. Chromosome numbers in the genus Cirsium. I. The Botanical Magazine (Tokyo) 48: 150-151.

Albers F., Pröbsting W. 1998. Chromosomenzahlen der Farn- und Blütenpflanzen Deutschlands. In: Standardliste der Farn- und Blütenpflanzen Deutschlands. Eds. R. Wisskirchen, H. Haeupler. Stuttgart: Verlag Eugen Ulmer. Pp. $562-616$. 
Bureš P., Wang Y. F., Horova L., Suda J. 2004. Genome size variation in Central European species of Cirsium (Compositae) and their natural hybrids. Annals of Botany 94: 353-363. DOI: 10.1093/aob/mch151

Frankton C., Moore R. J. 1961. Cytotaxonomy, phylogeny, and Canadian distribution of Cirsium undulatum and Cirsium flodmanii. Canadian Journal of Botany 39: 21-33.

Frankton C., Moore R. J. 1963. Cytotaxonomy of Cirsium muticum, Cirsium discolor, and Cirsium altissimum. Canadian Journal of Botany 41: 73-84.

Häffner E., Hellwig F. H. 1999. Phylogeny of the tribe Cardueae (Compositae) with emphasis on the subtribe Carduinae: an analysis based on ITS sequence data. Willdenowia 29: 27-39. DOI: 10.3372/wi.29.2902

Hedberg I., Hedberg O. 1977. Chromosome numbers of afroalpine and afromontane angiosperms. Botaniska Notiser 130: 1-24.

Levan A., Fredga K., Sandberg A. A. 1964. Nomenclature for centromeric position on chromosomes. Hereditas 52(2): 201-220. DOI: 10.1111/j.1601-5223.1964.tb01953.x

Lövkvist B., Hultgård U. M. 1999. Chromosome numbers in south Swedish vascular plants. Opera Botanica 137 : $1-42$.

Melahat O., Hayirlioglu-Ayaz S., Inceer H. 2008. Chromosome counts of some Cirsium (Asteraceae, Cardueae) taxa from Turkey. Caryologia 61(4): 375-382. DOI: 10.1080/00087114.2008.10589649

Nouroozi M., Sheidai M., Attar F., Noormohammadi Z. 2010. Contribution to cytotaxonomy of Iranian Cirsium (Asteraceae). Cytologia 75(1): 119-127. DOI: 10.1508/cytologia.75.119

Nouroozi M., Sheidai M., Attar F., Noormohammadi Z. 2011. B-chromosome and cytomixis in Cirsium (Asteraceae). Cytologia 76(1): 41-47. DOI: 10.1508/cytologia.76.41

Ownbey G. B., Olson W. A. 1969. Cytotaxonomic notes on the species of Cirsium native to the Southeastern United States. Rhodora 71: 285-296.

Ownbey G. B., Raven P. H., Kyhos D. W. 1975. Chromosome numbers in some North American species of the genus Cirsium. III. Western United States, Mexico, and Guatemala. Brittonia 27: 297-304. DOI: 10.2307/2805509

Paszko B. 2006. A critical review and a new proposal of karyotype asymmetry indices. Plant Systematics \& Evolution 258: 39-48. DOI: 10.1007/s00606-005-0389-2

Petrak F. 1979. Cirsium. In: Flora Iranica 139a. Ed. K.H. Rechinger. Graz: Akademische Druck-u Verlagsanstalt. Pp. 231-280.

Sheidai M., Seif E., Nouroozi M., Noormohammadi Z. 2012. Cytogenetic and molecular diversity of Cirsium arvense (Asteraceae) populations in Iran. Journal of Japanese Botany 87: 193-205.

Tonian T. R. 1981. New chromosome numbers of species of Cirsium Mill. from Armenia. Biologicheskii Zhurnal Armeni 34: 641-645.

Tonian T. R. 1982. New chromosome numbers of the species of Cirsium in Armenia. Ucenye Zapinski Erevan Universiteta 3: 115-120.

Yildiz B., Arabaci T., Dirmenci T., Köstekci S. 2016. A taxonomic revision of the genus Cirsium Mill. sect. Cirsium (Asteraceae: Cardueae) in Turkey. Turkish Journal of Botany 40: 514-530. DOI: 10.3906/bot-1503-35

Yüksel E., Kiran Y., Şahin A., Yildiz B., Arabaci T. 2013. Karyological studies of 10 Cirsium sect. Epitrachys (Asteraceae) species from Turkey. Turkish Journal of Botany 37: 1085-1092. DOI: 10.3906/bot-1302-1

Zarco C. R. 1986. Anew method for estimating karyotype asymmetry. Taxon 35(3): 526-530. DOI: 10.2307/1221906

Zomlefer W. B. 1994. Guide to flowering plant families. Chapel Hill and London: University of North Carolina Press. 430 pp. 